\title{
THE QUALITY OF NOTES RELATING SME REVENUES AND EXPENDITURES DISCLOSURES: EMPIRICAL STUDY OF CROATIAN FINANCIAL REPORTING STANDARS (CFRS) IMPLEMENTATION
}

\author{
Lorena Mošnja - Škare ${ }^{a}$, Adriana Galant ${ }^{b}$ \\ A Full Professor, PhD, Juraj Dobrila University of Pula, Faculty of Economics and Tourism "Dr. Mijo Mirković", \\ Preradovićeva 1/1, Pula, Croatia, Imosnja@unipu.hr.

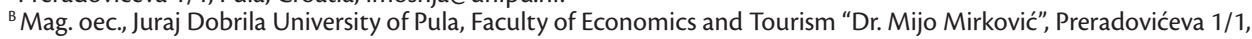 \\ Pula, Croatia, agalant@unipu.hr.
}

\section{ARTICLE INFO}

JEL classification: M41

Keywords:

- financial reporting standards

- notes

- SME

- revenues

- expenditures

\section{ABSTRACT}

This paper explores the quality of Croatian SMEs financial reporting notes relating disclosures upon revenues and expenditures, examining in such a way the level of CFRS implementation in this selected field of reporting. The goal is to determine the level of CFRS implementation in the selected field of reporting, over the SMEs group to notice any difference in their application between small and medium entities in order to assess their applicability for smaller entities. The notes contents and quality were found significantly correlated with SME size, raising the questions upon the CFRS requirements applicability by small, particularly the smallest micro-entities. 


\section{INTRODUCTION}

SMEs are considered as crucial engine of countries' economic growth and development. It is important for every country to create a suitable environment for running of their business. This also stands for the convenience of their financial reporting framework. SMEs financial reporting should not present a burden to their business requiring significant additional resources. It differs from country to country - in some countries it is based on IFRS for SMEs, or on full IFRS, while some countries introduce national standards meeting the specifities of SMEs operating in a given country. Instead of standards, it can also be founded on requirements defined by company law, tax regulation, state statistics, etc.

This paper is focused on SMEs notes to the financial statements, in terms of information quality provided to their users. Notes present an integral part of financial reports that all companies prepare for each financial year. They contain additional and complementary information relating to items presented in the balance sheet, profit and loss account, the statement of changes in owners' equity and cash flow statement. Notes to financial statements, often neglected by SMEs, are unavoidable source of information necessary for proper understanding of financial statements. ${ }^{1}$

In Croatia, SMEs must prepare their financial statements, including notes, according to national standards - Croatian Financial Reporting Standards (CFRS). CFRS, introduced in 2008, are issued by Croatian Financial Reporting Standards Board (CFRSB). CFRS are based on the accounting theory and Croatian accounting practice, International Financial Reporting Standards (IFRS) and on IV and VII EU Directives. ${ }^{2}$ Although CFRS are founded on IFRS, they are simpler and shorter then IFRS and intended to follow the needs of SMEs. ${ }^{3}$ Before 2005, SMEs applied International Accounting Standards (IAS), just like larger enterprises, while from 2005 to 2008, large enterprises applied IFRS and SMEs could choose between IFRS or the last adopted version (2004) of IAS in Croatia.

CFRS were introduced in order to reach high quality, transparent, comparable financial reports, so sticking to their requirements could be considered as a proxy for high quality reporting. Actually, they serve as the criteria for financial reports assessment.

This paper provides the empirical results upon the quality of Croatian SMEs financial reporting notes relating revenues and expenditures disclosures, by examining the level of Croatian financial reporting standards (CFRS) implementation in this selected field of reporting.

The target group for this research were not-listed SMEs, obliged to implement CFRS by Croatian accounting act. We analysed notes on revenues and expenditures, supposing all SMEs are at least to some extent exposed to transactions related with revenues and expenditures.

The empirical results were presented, raising some questions upon the possibilities of following the CFRS requirements by smaller entities. Is the goal of reaching transparent, high-quality, comparable SME financial reports based on CFRS really accomplished, if there's low level of their

\footnotetext{
${ }^{1}$ NikolinaDečman, "Financijskiizvještajikaopodlogazaocjenusigurnosti i usješnostiposlovanjamalih I srednjihpoduzeća u RepubliciHrvatskoj", Ekonomskipregled 63, no. 7-8 (2012), 449

${ }^{2}$ NikolinaSmrekar, "Usklađivanjenacionalne i međunarodne regulative financijskogizvještavanjamalih i srednjihpoduzeća”, ZbornikEkonomskogfakulteta u Zagrebu 7. no. 2 (2009), 90

${ }_{3}^{3}$ Maria G. Baldarelli et al., "Accounting harmonization for SMEs in Europe: Some remarks on IFRS for SMEs and empirical evidence", Ekonomskaistraživanja 25, SE 1(2012)
} 
implementation by small entities in the group of SMEs? This question is linked to similar questions raised in the literature upon the reasons for SMEs differential reporting. Our goal is to contribute to the latter debate by conclusions based on empirical research among Croatian SMEs that make the debate deeper focused towards insights in SMEs-intended financial reporting standards implementation by small enterprises cohort in the group of SMEs.

\section{THEORETICAL BACKGROUNDS}

Considering SMEs' role in economies' growth and development, each field of their work requires attention, including their accounting and financial reporting topics. Instead of providing a high quality basis for successful decision making, financial reporting sometimes grows more towards the burden than the business supporting system, making the reporting costs to prevail its benefits for financial reports' users. According to some authors SMEs have difficulties with financial reporting because of: ${ }^{4}$

- direct costs resulting from financial statements preparation,

- opportunity costs arising from missed opportunities to spend limited resources to other purposes, instead of financial reporting,

- direct reporting burden because of which small companies with for example, only one activity, can find themselves disadvantaged compared to larger competitors with diversified activities, unless they have to prepare detailed reports on segments and

- additional opportunity costs, which may be result of following legal framework, when other more appropriate ways are disabled.

Financial statements of all business entities, including SMEs must be of high quality to provide useful information to their users. The main stakeholders that are interested in SMEs financial reporting are: the owner-managers, the stakeholders not involved in the management of the firm, the bank and the tax authorities. ${ }^{5}$ The problem of SMEs is that, in general, they are not able to satisfy the information needs of their stakeholders. ${ }^{6}$ Regarding the financial reports users' needs, Deaconu, Silva and Popa ${ }^{7}$ performed one research to identify the SMEs stakeholders needs. According to them, SMEs specific stakeholders needs from the point of view of financial reporting and accounting information quality are: intelligibility, reliability, relevance, comparability and transparency. They concluded that the first step towards differential accounting reporting is the analysis of specific stakeholders and their needs. ${ }^{8}$ Regarding the financial statements users, Cole, Branson and Breesch, performed a research to find out whether the users of financial statements of publicly and non-publicly traded companies are different or not. Their results can be system-

\footnotetext{
${ }^{4}$ Bryan Carsberget. al., "Small Company Financial Reporting”, Prentice Hall International- ICAEW, London (1985).

${ }^{5}$ Maria-Gabriella Baldarelli, Paola Demartini and Lorena Mošnja-Škare, "International accounting for SMEs: Empirical evidence from SMEs in a country in transition and a developed country facing new challenges, (Pula: JurajDobrila University of Pula, 2007.) 25

'Paola Demartini and Eugenia Palazzi, "Basel 2 effects on SME financial reporting" in "Accounting for SMEs: Multidimensional aspects and global challenges” ed. Lorena Mošnja- Škare (Pula: JurajDobrila University of Pula, 2007.), 39

${ }^{7}$ Adela Deaconuet. al., "Analysis of the stakeholders' needs and their inference upon financial report of SMEs", Journal of international business and economics, vol 9, No. 1 (2009), 50

${ }^{8}$ Adela Deaconuet. al., "Analysis of the stakeholders' needs...", 47
} 
atized as follows?:

- suppliers, competitors, customers and consultants use financial statements of listed companies less then shareholders and investors,

- private users are more interested in financial statements of listed companies,

- professional users of financial statements of listed companies are analysts, financial managers and academics, while professional users only interested in non-listed companies are business owners and accountants,

- users of financial statements of non-listed companies tend to consult more financial statements but focus more on companies located in their own home-country and spend less time per financial statement.

SMEs financial reporting can be founded on accounting principles, company law, statistics' requirements, tax regulation or on a set of reporting standards. The widely accepted set of standards intended to become the global set of standards are International Accounting Standards, later International Financial Reporting Standards, created in the first place for publicly accountable, large, complex entities. Smaller entities are usually more ready to follow local frameworks. Actually, the debate upon the possibilities of IAS/IFRS implementation by SMEs and the need for the differential reporting towards local GAAP has been going on over few decades. A number of reasons analysed in the literature can be systematized ${ }^{10}$ in short as follows:

- cost of providing data as required by IFRS (Bollen, 1995),

- tax accounting (Guenther and Hussein, 1995 and Lamb et al., 1998; Haler, 2002; Street and Larson, 2004),

- different user needs (Page, 1984; Barker and Noonan, 1996; Collis and Jarvis, 2000; Paoloni and Demartini, 1997, / also Demartini 2006, 2007/; Riistama and Vehmanen, 2004; Hussey and Hussey, 1997; Chaveau et al., 1996; Friedlob and Plewa, 1992, Knutson and Wichmann, 1984; Lippitt and Oliver, 1983; Mcmahon, 2001; Haller, 2002; Chazen and Benson, 1978; Harvey and Walton, 1996; John and Healeas, 2000). According to John and Healeas (2000), "very few of the owner-managers have a proper understanding of the contents of statutory accounts... They often take the view that the statutory accounts are of no practical use for decision making and prefer to use the management accounts and a cash flow forecast". In addition, "because of the limited access of a small business to capital markets, the role of bankers and other short-term creditors is rather significant. A case can thus be made for making the focus of small business financial reporting the liquidity information needs of their short-term creditors, not general purpose GAAP, which focuses more upon income measurement" (Lippitt and Oliver, 1983, p. 54).

\footnotetext{
9 Vicky Cole, Joël Branson and Diane Breesch, Are users of financial statements of publicly and non-publicly traded companies different or not? An empirical study.accessed at January, 19, 2014. (http://papers.ssrn.com/sol3/papers. cfm?abstract_id=1407566)

${ }^{10}$ VeerleVansteeger, "The current state of accounting harmonization: impediments to and benefits from harmonization," working paper D/2005/7012/40, Department of Accountancy and Corporate Finance, Ghent UniversityAugust 2005, $2005 / 322$.
} 
- compliance with financial disclosure regulations (Bollen, 1995; Ingram et al., 1977; Robert; Ramsay and Sutcliffe, 1986).

According to Hagigi's systematization ${ }^{11}$ of positive and negative aspects for differential accounting measurement and disclosure based on previous studies, in favour of differential reporting there are differences in users' needs, access to internal information, complexity of transactions and there are higher costs for small companies relative to their benefits, while on the other side - against different sets of GAAP, there are fear of reducing the credibility, confusion among the statement users, difficulties of defining the small business, the lack of consistency and comparability. Like Di Pietra, R." ${ }^{2}$ noticed "Within the same EU context there are, at least, 4 different set of rules to prepare financial statements. We are facing with a sort of segmentation of the financial statements in respect to the categories to which a firm belong."

Analysing the need for accounting standards for SMEs ("Little GAAP"), Morris, P. and Campbell, J. ${ }^{13}$ came to the conclusion: "What is clear from the Big GAAP-Little GAAP initiatives is that there is a significant demand both in the US and internationally for an alternative form of GAAP for companies that are not publicly traded. The factors driving this demand for a second GAAP are: the needs of users, and the cost of using current GAAP. Moreover, the some authors ${ }^{14}$ wonder: "Is it really the needs of the users or is it the dissatisfaction of many accounting practitioners with the complex nature of current GAAP? When surveyed, it is that group that finds the greatest "challenge" to "keep current and up-to-date" with GAAP (AICPA Comparisons 52-54). We look forward to seeing continuing activity in both the US and internationally. We must always remember, whatever the outcome in this debate, what is important is that we meet the fundamental objective of accounting and financial reporting: to provide useful information for decision making." 15

Identifying the main reasons for and against differential reporting for SMEs, Evans et. al. systematized that the main arguments for differential reporting are the undue burdens and disproportionate costs of reporting carried by smaller businesses (Harvey and Walton, 1996, with reference to the UK) in spite of some existing exemptions (Bollen, 1996, with reference to the Netherlands). ${ }^{16}$ The same authors state some other arguments for differential reporting: perceived lack of relevance of (full) statutory financial statements to SME accounts users, in particular for internal reporting purposes (Harvey and Walton, 1996), narrower user groups, usefulness for a narrower range of decisions, less complex transactions and less need for sophisticated analysis of highly aggregated information (Collis et al., 2001). ${ }^{17}$ On the other hand, the main argument against differential reporting is the need for universality, what means that companies should not

\footnotetext{
${ }^{11}$ Moshe Hagigi, "Accounting Disclosure: Small Versus Large Companies", in L'armonizzazione dei principi contabili in Europa. "Quali regole" per le piccole e medie imprese?, ed. Gianfranco Capodaglio and Maria G. Baldarelli (Roma, Rirea, 2006), 243,244.

${ }^{12}$ Roberto Di Pietra, "IFRS for SMEs and EU Accounting Directives Modernization" (paper presented at EAA 33rd Annual Congress, Istanbul, May 2010.)

${ }^{13}$ Paula Morris and Jane Campbell, "Big GAAP-Little GAAP - Does One-Size-Fits-All Still Work?", Journal of Business \& Economics Research Vol. 4, No. 5, (2006), 79

${ }^{14}$ Morris and Campbell, "Big GAAP-Little GAAP", 81

${ }^{15}$ Mošnja-Škare, Lorena, "Accounting Standards for Small and Medium Enterprises in Croatia", in L' ipotesi di espansione in Europa degli IAS/IFRS, ed. Gianfranco Capodaglio (Roma, Rirea, 2011), 227-229.

${ }^{16}$ Lisa Evans et al., "Problems and opportunities of an International Financial Reporting Standards for Small and Mediumsized Entities. The EAA FRSC's Comment on the IASB's Discussion Paper, Accounting in Europe, vol. 2 (2005), 25-26
} 
be subject to different rules. ${ }^{18}$ Beside the need for universality, other reasons against differential reporting are the need for comparability and reliability, the public interest argument, the fear of making smaller companies 'second class citizens', the perceived threat that larger companies would press for similar advantages (Harvey and Walton, Barker and Noonan, Collis et al.), and the risk of the creation of a two-tier accounting profession (Collis et al., 2001). ${ }^{19}$

Beside the researchers, some international organizations have proposed their suggestions about SMEs financial reporting framework. Efforts in this topic were invested particularly by UNCTAD-ISAR with guidelines for SMEs and IASB with IFRS for SMEs.

UNCTAD (United Nations Conference on Trade and Development) recognized the problem about SMEs financial reporting. They established the Intergovernmental Working Group of Experts on International Standards of Accounting and Reporting (ISAR), which aim was to define internationally acceptable financial reporting standards for SMEs. ISAR supported the work of IASB (International Accounting Standards Board) and IAS (International accounting Standards), but it has often been difficult to apply IAS by SMEs, particularly by those in developing countries and countries with economies in transition. ${ }^{20}$ In 2003, ISAR proposed "Accounting and financial reporting guidelines for small and medium-sized enterprises (SMEGA)". The structure of guidelines was based on three-tiered model (UNCTAD, 2004):21

- Level 1: listed enterprises, which securities are publicly traded and those with public accountability (they should apply full IAS/IFRS issued by the IASB),

- Level 2: business enterprises that do not issue public securities and without public accountability (they should apply ISAR's single set of principles derived from the IAS issued by the IASB),

- Level 3: the smallest entities (they should apply simple accrual-based accounting).

The other organization that proposed a solution for SMEs financial reporting is International Accounting Standard Board (IASB). They issue IFRS, but have realized their inadequacy and complexity for SMEs, leading to the set of IFRS for SMEs, issued in 2009. Main characteristics of IFRS for SMEs are as follows ${ }^{22}$ :

- 230 pages,

- simplified IFRSs, but built on an IFRS foundation,

- completely stand-alone,

- designed specifically for SMEs,

- internationally recognized,

- $\quad$ final standards issued 9 July 2009.

\footnotetext{
${ }^{17}$ Evans et. al., "Problems and opportunities...", 26

${ }^{18}$ Evans et. al., "Problems and opportunities...", 26

${ }^{19}$ Evans et. al., "Problems and opportunities...", 27

${ }^{20}$ UNCTAD, "Accounting and financial reporting guidelines for small and medium-sized enterprises (SMEGA), Level 2 guidance", (New York and Geneva: United Nations, 2004), accessed at August 13, 2013, http://unctad.org/en/Docs/ iteteb20035_en.pdf

${ }^{21}$ UNCTAD, "Accounting and financial"

22 Paul Pacter and Darrel Scott, "The IFRS for SMEs" (paper presented at IFRS Conference, Dubai, September 14, 2012), accessed August 14, 2013, http://www.ifrs.org/IFRS-for-SMEs/Documents/1209SMEsDubai.pdf)
} 
Although IFRS for SMEs are based on full IFRS, there are significant differences that are particular for IFRS for SMEs ${ }^{23}$

- alternatives reduction in standards,

- simplification of methods for recognition and measurement,

- elimination of standards irrelevant for this category of enterprises,

- simplification of disclosure requirements and

- lower frequency of standards change.

In September 2012 more than 80 jurisdictions all over the world have adopted IFRS for SMEs (e.g. Argentina, Brazil, Egypt, Singapore, Turkey, Bosnia, Estonia, Macedonia, available for use in Switzerland, USA and Canada) or have started a plan to adopt it within the next three years (United Kingdom, Ireland, Denmark, Latvia) ${ }^{24}$. Organizationally, IFRS for SMEs aren't a lot different then full IFRS, but the differences can be noticed quantitatively because of the scope reduction for more than $90 \%$ (full IFRS have more than 2.500 pages, while IFRS for SMEs have 230 pages). ${ }^{25}$

The opinions about the possible implementation of IFRS for SMEs in the European Union level are different. The respondents in one of the studies performed believe that the Standards are best suitable for Large and Medium-sized companies, for international groups, for subsidiaries and for companies active internationally. Also they believe that by using them, harmonization and comparability will be improved and foreign investors will be more interested in European affairs. ${ }^{26}$ Main benefits of using IFRS for SMEs as the regulatory legal framework for financial reporting at EU level can be systematized like following ${ }^{27}$ :

- standards allow international comparability of financial reports,

- standards provide more harmonized information for stakeholders,

- implementation of these standards allows the use of the same accounting language,

- standards give important support to the prepares about consolidated accounts,

- companies that have subsidiaries in different member states can use these standards,

- facilitated cross border trade, foreign mergers and acquisitions and international growth of companies (European Commission),

- $\quad$ using the same standards will increase confidence in global financial reporting and will increase satisfaction of the needs of users of financial statements (Grosu and Bostan),

- increased comparability will make the financial statements analysis easier.

\footnotetext{
${ }^{23}$ BrankaRamljak and Katarina Žager, "Stanje i razvojfinancijskogizvještavanjamalih i srednjihpoduzeća u RH i EU", Računovodstvo i financije, vol. 59, No. 7 (2013), 27.

${ }^{24}$ Pacter and Scott, "The IFRS for SMEs"

${ }^{25}$ Smrekar, "Usklađivanjenacionalne", 94.

${ }^{26}$ Ana-Maria Pascu and AndreeaVasiliu, "International financial reporting standard for small and medium-sized entities

- a new challenge for the European Union", Centre for European Studies (CES) Working Papers, Vol. 3 Issue 1 (2011): 128

${ }^{27}$ Pascu and Vasiliu, "International financial reporting", 128-129
} 
At the same time, the implementation of IFRS for SMEs will lead to some important costs. The reasons for additional costs are the following ${ }^{28}$ :

- the standards are too complex and their implementation means new methodology, redesign of internal processes, staff education about

- stakeholders are used to current accounting regulation;

- the need to prepare a second set of accounts for tax purpose can be expensive, if the government requests it and if there are important differences between the IFRS for SMEs and national regulations.

- for companies that operate only locally, implementation of IFRS for SMEs has no benefits

- the development of a common educational framework for accountants (European Commission, 2010a).

Quagli and Paoloni ${ }^{29}$ analysed IFRS for SMEs from perspective of external users and preparers of financial reports. Their research was based on answers given by responders to the official "Questionnaire on the public consultation of the IFRS for SMEs" from the European Commission. The results show that there is a strong difference between users and preparers and also between countries as well, regarding their opinion for implementation of IFRS for the SMEs. According to the results, preparers of financial reports are against implementation of IFRS for SMEs, while users are more favourable. Regarding the difference between countries, they found that Germanspeaking countries and Latin countries are more opposed to them then Anglo-Nordic countries. ${ }^{30}$

The debate has continued towards micro-entities since IFRS for SMEs seemed to be still too much complex and burdened by a lot of application problems. According to an IASB member and chairman of the SME Implementation Group, Paul Pacter: "The IFRS for SMEs has been a remarkable success story with around 80 jurisdictions having already adopted or planning to adopt the 230 page standard." IASB has gone on with this project towards the micro entities, recognizing their needs and have developed a guidance to help them apply the IFRS for SMEs. The IASB SME Implementation Group has extracted from IFRS for SMEs the requirements necessary for a typical micro-sized entity, keeping the recognition and measurement principles as set by IFRS for SMEs and providing further guidance and illustrative examples, as well as cross-references to the IFRS for SMEs for topics not covered by the guidance. Since the IFRS for SMEs are not modified, the reference to conformity with the IFRS for SMEs is allowed for the guidance users. ${ }^{31}$

Regardless of these global initiatives intended for SMEs and micro-sized entities' financial reporting, some countries have decided to implement their own national set of standards or local GAAP (Generally accepted accounting principles) for this particular segment of enterprises. National standards are adapted to the particular environment in which SMEs operate.

\footnotetext{
${ }^{28}$ Pascu and Vasiliu, "International financial reporting", 129

${ }^{29}$ Alberto Quagli and Paola Paoloni, "How is the IFRS for SMEs accepted in the European context? An analysis of the homogeneity among European countries, users and preparers in the European commission questionnaire", Advances in accounting, Vol. 28, No. 1 (2012), 147

${ }^{30}$ Quagli and Paoloni, "How is the IFRS for SMEs accepted in the European context?, 147

31 "Guidance for micro-sized entities," IASB, accessed August 24, 2013, http://www.ifrs.org/IFRS-for-SMEs/Pages/

Guidancemicrosizedentities.aspx
} 
Croatia has also decided to implement national set of standards for SMEs, but taking account in the same time upon financial reporting harmonization goals, keeping them based on IFRS and EU Directives. Croatia was a country in transition, which became full member of European Union on July 1, 2013. It is interesting to compare its experiences and reporting developments with other former transition countries. Albu et. al. ${ }^{32}$ performed one research streaming to analyze the possibility of IFRS for SMEs implementation in some European former transition countries (The Czech Republic, Hungary, Romania). For Czech Republic, Hungary and Romania, they found out that accounting regulation is not fully harmonized, that there are conceptual problems in the current regulations and that accounting regulations are influenced by taxation and have a rule-oriented approach. ${ }^{33}$ The same authors proposed and analyzed three different scenarios for possible implementation of IFRS for SMEs. These are ${ }^{34}$ :

1. adoption of the standards only for some SMEs (mainly based on a coercive-type of isomorphism)

2. the voluntary adoption of the IFRS for SMEs, (a mimetic-type of isomorphism)

3. convergence of the national regulations and standards with the IFRS for SMEs, with the input of the accounting profession and professional bodies (normative isomorphism).

According to the research results the best option for countries involved in their research (The Czech Republic, Hungary, Romania and Turkey) is the convergence of national regulation and standards with IFRS for SMEs, education of accounting profession and the business environment. ${ }^{35}$ The results and conclusions of their research could also be considered for other European former transition countries.

\section{SMEs FINANCIAL REPORTING IN CROATIA}

SMEs take a significant share of Croatian economy, accounting for $99,63 \%{ }^{36}$ of all entities in Croatia. In April 2013, there were 96.330 small entities, 1.299 medium-sized entities and 360 large entities (which submitted financial statements) in Croatia. ${ }^{37}$ In 2010, SMEs produced 51,6\% of Croatian GDP, employing $66,4 \%$ of employees and participating with $41,2 \%$ in Croatian exports (CEPOR, 2011).

Croatian Accounting Act introduced in 2008, classifies business entities by their size in three groups: small, medium-sized and large entities, depending on meeting two out of three criteria: total assets, revenues and average number of employees. Since criteria are defined in official Croatian currency: kuna (abbreviation: HRK), they are translated into euros for comparison

\footnotetext{
${ }^{32}$ CătălinNicolaeAlbuet. al., "An Analysis of the Suitability of the IFRS for SMEs Implementation in Romania, the Czech Republic, Turkey and Hungary", International Conference, Accounting Renaissance, Lessons from the Crisis and Looking into the Future, Learning from Histories and Institutions, Universita Ca' Foscari, IAAER, Financial Reporting Journal, (Venice, 3-5 November 2011, 23

${ }^{33}$ Albuet. al., "An Analysis of the Suitability of the IFRS for SMEs Implementation...", 23

${ }^{34}$ Albuet. al., "An Analysis of the Suitability of the IFRS for SMEs Implementation...", 24

${ }^{35}$ Albuet. al., "An Analysis of the Suitability of the IFRS for SMEs Implementation...", 24

36 "BIZNET - inteligentnisustavposlovnihinformacija", accessed April 05, 2013. http://www1.biznet.hr/hgkweb/do/ advsearch.

37 "BIZNET"
} 
purposes (average exchange rate in 2012 was $1 \mathrm{EUR}=7,5175 \mathrm{HRK}^{38}$ ).

Small entities are those who do not exceed two of the following criteria:

- total assets of HRK 32,5 million, approx. EUR 4,32 million,

- revenues of HRK 65 million, approx. EUR 8,65 million and

- $\quad$ average number of employees: 50 .

The second group of business entities are medium-sized entities. Medium-sized entities are the ones that exceed two of criteria stated above for small entities, but do not exceed two of the following criteria:

- total assets of HRK 130 million, approx. EUR 17,29 million,

- revenues of HRK 260 million, approx. EUR 34,59 million and

- $\quad$ average number of employees: 250 .

The last group of entities are the large ones. Large enterprises are the ones that exceed at least two of criteria stated above for medium-sized entities. In addition, large business entities are also financial institutions, regardless of their total assets, revenues and average number of employees, like: banks, saving banks, insurance companies, leasing companies, retirement funds etc.

If we compare these Croatian criteria with definition criteria for small and medium-sized enterprises in European Union, we will see that there is no difference because of harmonization with requirements of EU Directives. ${ }^{39}$

International Accounting Standards Board (IASB) defines SMEs differently than Croatian Act and European Union Directives. According to IFRS for SMEs, small and medium-sized enterprises are the ones that: ${ }^{40}$

- do not have public accountability.

- publish general-purpose financial statements for external users.

Considering large number of SMEs in Croatia, it is necessary to mention their classification regulated by Act on supporting of small entrepreneurship development. ${ }^{41}$ This Act uses the term small enterprises for the whole group of SMEs, classifying them into three groups: micro, small and medium- sized.

Micro entities among SMEs are the ones that meet the following criteria:

- annual average number of employees less than 10 and

- operating revenues up to EUR 2 million or total assets up to EUR 2 million (for profit tax payers), and fixed assets value up to EUR 2 million (for income tax payers).

\footnotetext{
38 "Exchange rates", Croatian National Bank, accessed August 8, 2013. http://www.hnb.hr/tecajn/

39 BrankaRamljak, "Stanje i perspektiverazvojafinancijskogizvještavanjaza mala i srednjapoduzeća", in: Računovodstveno izvještavanje u RH i harmonizacijasazahtjevima EU, ed. BrankaRamljak (Split: Ekonomskifakultet, 2009), 23

40 "IFRS for SMEs", IASB, accesed August 11, 2013.http://eifrs.iasb.org/eifrs/sme/en/IFRSforSMEs2009.pdf

${ }^{41}$ Croatian act on supporting of small entrepreneurship development, The official gazette - NN, 29/02, 63/07, 53/12, $56 / 13$.
} 
Small entities among SMEs include the ones complying with the following criteria:

- annual average number of employees less than 50 and

- operating revenues up to EUR 10 million or total assets up to EUR 10 million (for profit tax payers), and fixed assets value up to EUR 10 million (for income tax payers).

Medium-sized entities employ more than 50 employees, with more than EUR 10 million operating revenues or more than EUR 10 million total assets/fixed assets. Their upper limit is determined by Accounting Act criteria as previously stated.

As well as classification of all enterprises, classification of SMEs in Croatia is also harmonized with the EU legislation. Table 1 shows SMEs classification as defined by EU.

TABLE 1 - EUROPEAN UNION SMES CLASSIFICATION

\begin{tabular}{|c|c|c|c|c|}
\hline Company category & Employees & Turnover & or & Balance sheet total \\
\hline Medium-sized & $<250$ & $\leq € 50 \mathrm{~m}$ & & $\leq € 43 \mathrm{~m}$ \\
\hline Small & $<50$ & $\leq € 10 \mathrm{~m}$ & & $\leq € 10 \mathrm{~m}$ \\
\hline Micro & $<10$ & $\leq € 2 \mathrm{~m}$ & & $\leq € 2 \mathrm{~m}$ \\
\hline
\end{tabular}

Source: http://ec.europa.eu/enterprise/policies/sme/facts-figures-analysis/sme-definition/(12.08.2013.)

European Union Directive for financial reporting of micro-entities was first presented in 2012. With this Directive EU proposes further accounting simplification for micro-entities and reducing of their administrative burden. The aim of this Directive is to enable Member States to create a simple financial reporting environment for micro-entities ${ }^{42}$.

Croatian SMEs prepare the financial statements as regulated by Accounting Act, which requires all the enterprises to prepare, and present annual financial statements based on CFRS. (Accounting Act, article 13, paragraph 1) Exception from this provision are large enterprises and enterprises that are listed or prepare for listing on an organised security market, which prepare and present their annual financial statements by application of IFRS. (Accounting Act, article 13, paragraph 2) So, SMEs, except the listed ones and the ones preparing for listing, prepare and present their financial statements by implementation of CFRS. SMEs included in the sample analysed should comply with the above provisions.

If we compare Croatian accounting regulative, regarding SMEs with some other ex communist countries in Europe, we notice that in some of them e.g. Slovenia, the Czech Republic, Bulgaria the SMEs can implement full IFRS or National accounting standards, while some others like Serbia, Bosnia and Herzegovina, Macedonia require them to implement IFRS for SMEs. ${ }^{43}$

\footnotetext{
${ }^{42}$ Directive 2012/6/EU of the European parliament and of the council of 14 March 2012 amending Council Directive $78 / 660 / \mathrm{EEC}$ on the annual accounts of certain types of companies as regards micro-entities, Official Journal of the European Union, L 81/3, 2012, accessed August 14, 2013. http://eur-lex.europa.eu/LexUriServ/LexUriServ.do?uri=O J:L:2012:081:0003:0006:EN:PDF

${ }_{43}$ IFRS application around the world, Jurisdiction Profiles, accessed January, 15, 2014., http://www.ifrs.org/Usearound-the-world/Pages/Jurisdiction-profiles.aspx
} 
Previously, Croatia has required SMEs to implement IAS in the period 1993-2007, until CFRS were introduced by Accounting Act in force from 2008, as a consequence of poor compliance with IAS that were too complicated for SMEs, and not in line with their user needs. That resulted in tax legislation becoming a key driver of SMEs reporting. Introducing of CFRS was an attempt to improve SMEs financial reporting to reach transparent, comparable, high quality reports in line with Croatian accounting practices, IFRS, IV and VII EU Directives. So, the level of CFRS implementation is considered as the criterion for reports and notes quality. However, some researchers argue that accounting standards are not the primary factor that determines the informativeness of financial reports, but enterprises' reporting incentives are the ones ${ }^{44}$ ). After five years of CFRS implementation, we try to assess if CFRS managed to fulfil their purpose. There is a question raised regarding the smallest entities, employing not more than five employees which count for about half of small enterprises and CFRS are considered still to be too wide framework for this cohort of enterprises. ${ }^{45}$ The need for differentiation of reporting requirements between small and "micro" entities is also outlined by Žager, K.. ${ }^{46}$

In our research, we considered not only "micro" entities, but also the whole cohort of small enterprises as defined by Croatian Accounting Act as target group to check for their compliance with CFRS in the selected field of reporting.

Compliance with CFRS is subject to compulsory financial statements auditing, regulated by Audit Act ${ }^{47}$ and Accounting Act. ${ }^{48}$ According to Audit Act, subject to compulsory auditing are all enterprises' financial statements (including consolidated financial statements) with total revenues above HRK 30 mil. Additionally, Accounting Act requires the auditing of financial statements of enterprises listed at organised security market or preparing for listing. The latter provision was irrelevant for this research since it referred to enterprises obligated to implement IFRS that were excluded from the sample.

\section{SAMPLE SELECTION, DESCRIPTIVE STATISTICS AND METHODS}

The sample comprised a hundred of Croatian not-listed SMEs financial reports and notes randomly selected (independently of their industry type, county, ownership, foundation date, etc.) from financial reports Register held by Croatian Financial agency for the year 2011. The only selection criteria was the entities' size, large entities were excluded. The research was performed in March - April 2013. Considering the total number of 97.629 SMEs ( 96.330 of small and 1.299 of medium enterprises, see chpt. III) in Croatia, the representative sample size would comprise 96 entities with 95\% level of confidence (Table 2).

\footnotetext{
${ }^{44}$ Ray Ball, S. P. Kothari and Ashok Robin, "The Effect of International Institutional Factors of Properties of Accounting Earnings," Journal of Accounting and Economics 29 (2000) and Ray Ball and LakshmananShivakumar, "Earnings Quality in UK Private Firms.," Journal of Accounting and Economics 39 (2005)

${ }^{45}$ Ramljak, "Stanje i perspektive", 43.

${ }^{46}$ Katarina Žager, "Osnovnaobilježja i značaj MSP u gospodarskomrazvoju”, in Harmonizacija i standardizacijafinanc ijskogizvještavanjamalih i srednjihpoduzeća,, ed. Katarina Žager, (RIF, Zagreb: HZRIF, 2013), 22.

${ }^{47}$ Croatian Audit Act, The official gazette - NN 146/05, 139/08, 144/12

${ }^{48}$ Croatian Accounting Act, The official gazette - NN 109/07, 54/13 
TABLE 2 - REPRESENTATIVE SAMPLE SIZE

\begin{tabular}{cc}
\hline Accepted margin of error & $\mathbf{1 0 \%}$ \\
\hline \hline Confidence level & $95 \%$ \\
$\quad$ Population size & 97.629 \\
Response distribution & $50 \%$ \\
Recommended sample size & 96 \\
\hline \hline
\end{tabular}

Source: http://www.raosoft.com/samplesize.html (05.04.2013.)

Regarding the legal form of enterprises, sample comprised two types of enterprises: limited liability company (Ltd.) and joint-stock company (Table 3).

TABLE 3 - THE LEGAL FORM OF ENTERPRISES INCLUDED IN THE SAMPLE

\begin{tabular}{cccc}
\hline \hline Legal form/size & Small & Medium - sized & Total \\
\hline \hline Limited liability company & 50 & 41 & 91 \\
Join-stock company & 0 & 9 & 9 \\
Total & 50 & 50 & 100 \\
\hline \hline Source: FINA Register of financial reports, 2011
\end{tabular}

Source: FINA Register of financial reports, 2011

The majority of the enterprises included in the sample are private companies ( 92 of 100 enterprises), while the rest are public companies (8 of 100 enterprises). Enterprises included in the sample were located in 16 different counties ${ }^{49}$, mostly in capital city of Zagreb (22\%), followed by Istrian county (14\%) and Primorje - Gorski Kotar County (13\%).

There were 46 enterprises in the sample obligated to perform financial statement audit and 54 enterprises were not subjects to annual audit.

Table 4 shows the detailed sample description comprising 11 descriptive items. Liquidity ratio was calculated as the ratio between current assets and short-term liabilities; leverage ratio was calculated as the ratio between total liabilities and total assets and return on assets (ROA) was calculated as the ratio between net profit or loss and total assets.

\footnotetext{
${ }^{49}$ Croatia consists in total of 20 counties plus Capital City of Zagreb
} 
TABLE 4 - SMES SAMPLE DESCRIPTION

\begin{tabular}{|c|c|c|c|c|c|c|}
\hline $\begin{array}{c}\text { Descriptive } \\
\text { item }\end{array}$ & Count & Mean & $\begin{array}{l}\text { Standard } \\
\text { deviation }\end{array}$ & Minimum & Median & Maximum \\
\hline $\begin{array}{c}\text { Employees } \\
\text { number }\end{array}$ & 50 & 78,68 & 109,41 & 0 & 63 & 646 \\
\hline Total assets & 100 & $66.228 .151,39$ & $159.588 .416,11$ & 1 & 25.409 .508 & 1.335 .683 .552 \\
\hline $\begin{array}{l}\text { Equity + } \\
\text { reserves }\end{array}$ & 100 & $39.064 .481,17$ & $151.205 .774,81$ & $(12.596 .488,00)$ & 1.797 .145 & 1.324 .507 .643 \\
\hline $\begin{array}{l}\text { Subscribed } \\
\text { capital }\end{array}$ & 100 & $30.050 .965,03$ & $144.787 .983,86$ & 18.000 & 25.895 & 1.324 .226 .000 \\
\hline Liabilities & 100 & 27.163.470,18 & $39.004 .677,49$ & - & 10.455 .426 & 197.407 .826 \\
\hline Revenues & 100 & 43.689.247,95 & $61.821 .775,78$ & - & 14.526 .759 & 350.280 .067 \\
\hline $\begin{array}{l}\text { Total expendi- } \\
\text { tures }\end{array}$ & 100 & $42.915 .931,98$ & $60.563 .041,15$ & 660,00 & 14.565 .836 & 350.116 .920 \\
\hline $\begin{array}{l}\text { Net profit or } \\
\text { loss }\end{array}$ & 100 & $533.958,29$ & $4.875 .148,80$ & $(16.548 .913,00)$ & $33.483,00$ & 37.139 .461 \\
\hline Liquidity ratio & 98 & 6,58 & 27,77 & - & 1,13 & 246,17 \\
\hline Leverage ratio & 100 & $9.276,78$ & $92.755,07$ & - & 0,79 & 927.552 \\
\hline ROA & 100 & $(16,91)$ & 170,02 & $(1.700,00)$ & 0,00 & 13,99 \\
\hline
\end{tabular}

Source: FINA Register of financial reports, 2011

Trying to assess the quality of notes, we explored the notes on revenues and expenditures disclosures, supposing that majority of SMEs would encounter transactions generating revenues and expenditures. The quality of notes was assessed by the authors, after a careful study of disclosed financial reports and related notes. The notes quality is graded according to the level of financial reporting standards implementation in their structuring and presentation.

The CFRS were introduced to reach high quality, transparent, comparable financial reporting and all Croatian SMEs, except the listed ones or the ones preparing for listing, are expected to follow CFRS in their financial reporting. CFRS 1 (Financial statements) requires the disclosure of information about the basis on which financial statements are founded. ${ }^{50}$ SMEs without the statement of CFRS implementation as the basis of their financial reports, although they were supposed and obliged to follow them, were graded with 1 or not in line with CFRS.

Those that quoted CFRS as the basis of reporting, were assessed for the quality of their notes on revenues and expenditures disclosures, searching for their compliance with CFRS 15 which refers to revenues, CFRS 16 which refers to expenditures and related disclosures in notes required by these standards.

CFRS 15 (Revenues) includes definitions of revenues, criteria for revenue recognition, as well as

${ }^{50}$ Croatian financial reporting standards, The official gazette - NN 30/08, 4/09, 58/11, 140/1, accessed August 10, 2013. http://www.porezna-uprava.hr/hr_propisi/_layouts/in2.vuk.sp.propisi.intranet/propisi.aspx\#id=pro1230 
its derecognition and disclosure requirements. According to this standard, following information should be disclosed:

- accounting policy for recognizing revenue (the amount of each of the types of material revenue, recognized in the accounting period; the amount of exchange rate differences, recognized in the profit and loss account; within each of material type of revenue, the amount of revenue from exchanges of goods or services; the amount, structure and type of other revenues or other expenditures recognized on net-basis and the amount, structure and type of other revenues),

- revenue upon construction contract (the initial amount of revenues, as contracted; changes of contracted work).

CFRS 16 (Expenditures) includes expenditures definitions, criteria for expenditures recognition, as well as its derecognition and disclosure requirements. The following disclosures are required:

- reasons of particular assets impairments and impairment methods,

- explanation of amounts disclosed as extraordinary expenditures,

- description, amounts and expected period of provisions - related economic benefits outflow,

- the amount of interest, as well as other borrowing costs capitalized during the period,

- net exchange rate differences, classified as a separate capital item,

- the amount of costs and losses recognized upon construction contracts,

- unexpected rents recognized as expenditure of a period,

- all other information as required by other standards or material to financial reports users for correct and complete understanding of business and

- accounting policy for borrowing costs.

The fulfilment of CFRS 15 and CFRS 16 disclosure requirements was graded from 1-5 (5the best notes, in line with all CFRS 15/16 disclosure requirements). Two groups of estimates were formed: in the first group there were entities, which notes were estimated as not in line with CFRS at all (grade 1), while entities with notes graded from 2-5, were all gathered together in the other group.

In terms of the logit model ${ }^{51}$,

$$
p=\frac{1}{1+e^{-\left(b_{0}+b_{1} x_{1}+b_{2} x_{12}+\cdots+b_{n} x_{n}\right)}}
$$

or in terms of an odds ratio

$$
\frac{p}{1-p}=\exp \left(b_{0}+b_{1} x\right)
$$

\footnotetext{
${ }^{51}$ Logistic Regression, accessed August 24, 2013, http://www.saedsayad.com/logistic_regression.htm
} 
or log-odds

$$
\ln \left(\frac{p}{1-p}\right)=b_{0}+b_{1} x
$$

the dependent variable "the quality of notes", was category variable for which the dummy variable was introduced. The latter group, with notes in line with CFRS, fell in the category (1), while the former one, with notes not in line with CFRS, fell in the category (0).

The relation between the dependent category variable - quality of notes and independent category variable - size (according to size criteria defined by Croatian Accounting Act, as previously presented in chpt. III) was tested, followed by univariate analyses including compulsory auditing (category variable), as well as total assets, liabilities, equity and reserves, revenues and expenditures (quantitative variables), as independent variables which logarithms served as proxies for enterprises' size.

Dependent variable:

Notes quality (following CFRS 15 and CFRS 16 disclosure requirements):

1-quality grade (2-5), CFRS followed

0 -quality grade (1), CFRS not followed.

Independent variables:

Size

1-medium enterprises

0 -small enterprises

Total assets, liabilities, equity and reserves, revenues, expenditures as proxies for size.

Compulsory auditing

1-subject to compulsory auditing

0 -not subject to compulsory auditing.

\section{HYPOTHESES AND RESEARCH RESULTS}

Considering our willingness to explore the level of CFRS implementation in financial reporting notes by Croatian SMEs comparing the group of small with the group of medium enterprises, our hypotheses were established as follows:

$\mathrm{H}$ 1: The quality of financial statements notes upon revenues and expenditures is correlated with the enterprises' size.

$\mathrm{H}$ 2: The quality of financial statements notes upon revenues and expenditures is correlated with the obligation to perform compulsory auditing.

The first hypothesis assumes that medium - sized entities' notes relating revenues and expenditures disclosures are of higher quality than smaller entities' ones due to higher level of CFRS compliance. CFRS are considered to be still too complex for small entities and that's why lower level of compliance is expected. The second hypothesis supposes that entities obligated to perform compulsory audit have higher quality of notes than those not subject to compulsory audit. Subjects to annual auditing are mostly larger entities in the group of SMEs, with annual revenues 
above HRK 30 million, so this variable can also serve as a proxy for size. The null hypotheses (H0) would suggest there's no correlation between notes quality and enterprises' size or compulsory auditing.

Here are the results presented below.

\section{$0<$ size $\leq 1$}

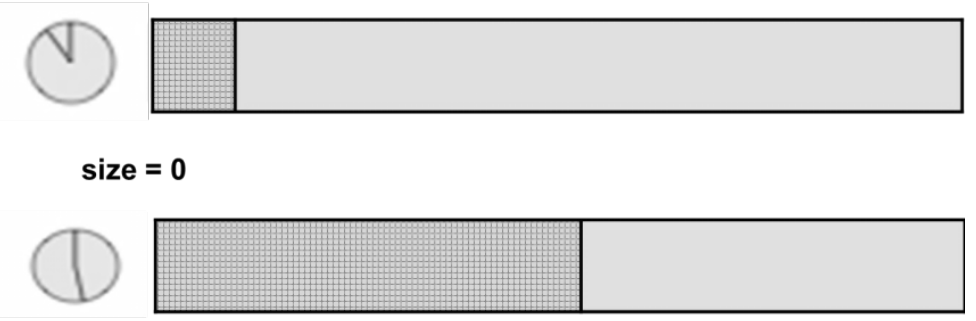

\section{Legend: Grade: 1}

\section{Grade: $2-5$}

\section{Source: Authors' calculation}

\section{FIGURE 1. THE QUALITY OF NOTES ASSESSEMENT BY SIZE}

It is obvious that among small enterprises (size 0), the share of low-graded notes (darker colour) is around half of the total number of enterprises while this stands only for a small share of medium enterprises. That means the quality of notes to financial statements of medium enterprises is higher (the majority was graded with 2-5) in comparison with the small ones' notes.

According to logit univariate regression results, the previous finding is statistically significant $(p<0,001)$ confirming the correlation between the quality of notes and enterprises' size $(B=2,342)$. The odds ratio suggests, the odds of having the notes in line with CFRS among medium enterprises is ten times the odds of having the notes in line with CFRS among small enterprises. 


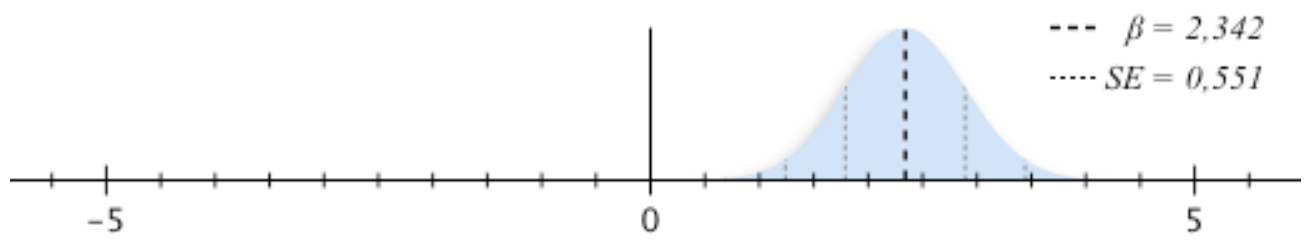

$[$ size $=1]$ estimated odds ratio

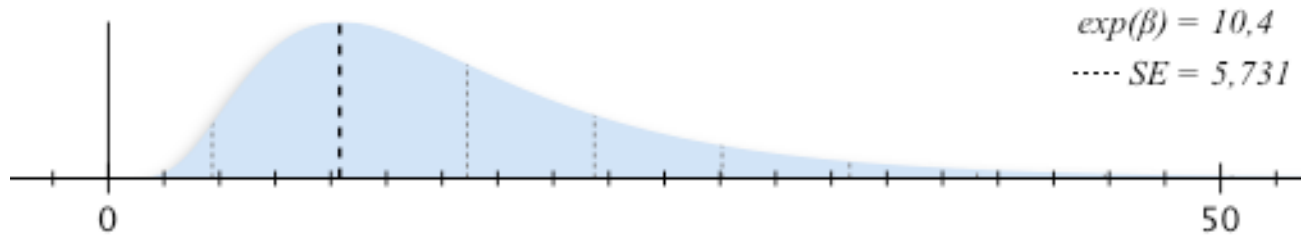

The receiver operating characteristic (ROC) curve graphically presents the predictive power of this binary-outcome model:

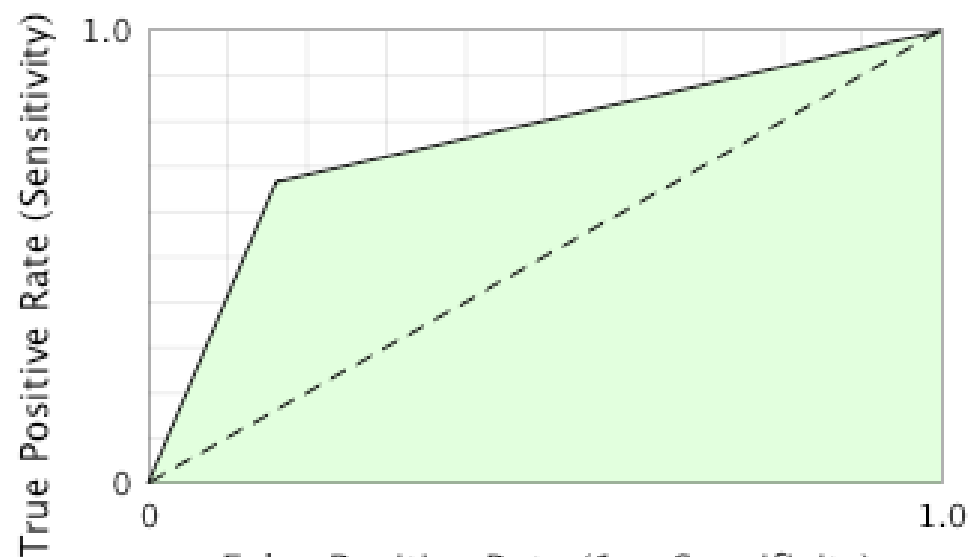

False Positive Rate (1 - Specificity)

\section{Area Under Curve $=0.7527$}

\section{FIGURE 2. THE UNIVARIATE LOGIT ANALYSIS RESULTS: QUALITY OF NOTES BY SIZE}

Source: Authors' calculation

The hypothesis $\mathrm{H} 1$ is confirmed, there is a significant relation between the quality of notes and enterprises' size implicating the medium entities' higher quality of notes upon revenues and expenditures disclosures in relation to small entities. The prediction rate is $53.1 \%$ for small enterprises and $9.8 \%$ for medium enterprises to have low-quality notes upon revenues and expenditures disclosures ( $A \cup C=0,7527$ ).

The hypothesis was also confirmed by univariate logit analyses results, performed employing a set 
of quantitative variables as proxies for size.

TABLE 2 - THE UNIVARIATE LOGIT ANALYSES RESULTS: QUALITY OF NOTES BY PROXIES FOR SIZE

\begin{tabular}{cccccccc}
\hline $\begin{array}{c}\text { Independent vari- } \\
\text { able }\end{array}$ & $\begin{array}{c}\text { Coefficient } \\
\text { (beta) }\end{array}$ & SE & P-value & $\begin{array}{c}\text { Log-likeli- } \\
\text { hood }\end{array}$ & ROC & $\begin{array}{c}\text { Odds } \\
\text { ratio }\end{array}$ & SE \\
\hline \hline Size & 2,342 & $-0,551$ & $P<0,001$ & $-50,230$ & 0,7527 & 10,400 & 5,731 \\
Compulsory auditing & 2,389 & 0,591 & $P<0,001$ & $-50,318$ & 0,7443 & 10,904 & 6,444 \\
Ln total assets & 0,216 & 0,073 & $P=0,003$ & $-56,706$ & 0,7513 & & \\
Ln equity/reserves & 0,226 & 0,082 & $P=0,006$ & $-46,749$ & 0,7124 & \\
Ln subscribed capital & 0,334 & 0,101 & $P<0,001$ & $-53,932$ & 0,7555 & & \\
Ln liabilities & 0,296 & 0,084 & $P<0,001$ & $-54,451$ & 0,759 & & \\
Ln total revenues & 0,188 & 0,063 & $P=0,003$ & $-52,119$ & 0,7592 & \\
Ln total expenditures & 0,222 & 0,065 & $P<0,001$ & $-55,468$ & 0,7489 & \\
\hline \hline
\end{tabular}

Source: Research results based on published financial reports and notes 2011, FINA Register of financial reports

At high confidence level above $99 \%$, it is confirmed there's significant correlation between the quality of notes upon revenues and expenditures disclosures and the proxies for size. That also indicates high multicollinearity among the independent variables, which is why they were not arranged together in a multivariate logit model, but in a row of univariate analyses instead.

In addition to the size, we were also interested to test for the existence of any relation between the quality of notes - their contents according to CFRS 15/16 disclosures requirements, and compulsory auditing. Actually, the enterprises subjects to annual auditing are definitely not the smallest ones (subjects to annual auditing are supposed to earn over HRK 30 million), so this variable can also serve as a proxy for size. Similarly to previous findings, the entities obliged to annual auditing were characterized by higher quality of notes and CFRS implementation in relation to other entities not obliged to perform the annual auditing (compulsory auditing $=0$ ). In the latter group, half of the entities had low-quality notes. 


\section{$0<$ compulsory auditing $\leq 1$}

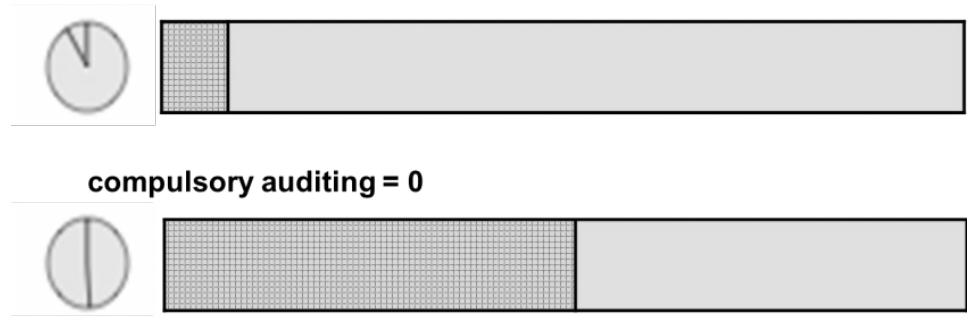

Legend: Grade: 1

Grade: 2-5

\section{FIGURE 3. THE QUALITY OF NOTES ASSESSEMENT BY COMPULSORY AUDITING CRITERION}

Source: Authors' calculation

The results confirm $\mathrm{H} 2$ indicating there is correlation between the quality of notes and obligation to perform compulsory auditing $(\beta=2,389)$, i.e., there is statistically significant difference in the quality of notes between the enterprises obliged and not obliged to perform annual financial reports audit, with the confidence level above $99 \%$.

The odds ratio suggests, the odds of having the notes in line with CFRS among enterprises obliged to perform annual audit is almost eleven times the odds of having the notes in line with CFRS among enterprises not subjects to annual audit.

The prediction rate is $50,9 \%$ for the enterprises not subjects to compulsory audit to have low-quality notes, while that stands for only $8,7 \%$ of subjects to compulsory audit ( $A \cup C=74 \%$ ). 


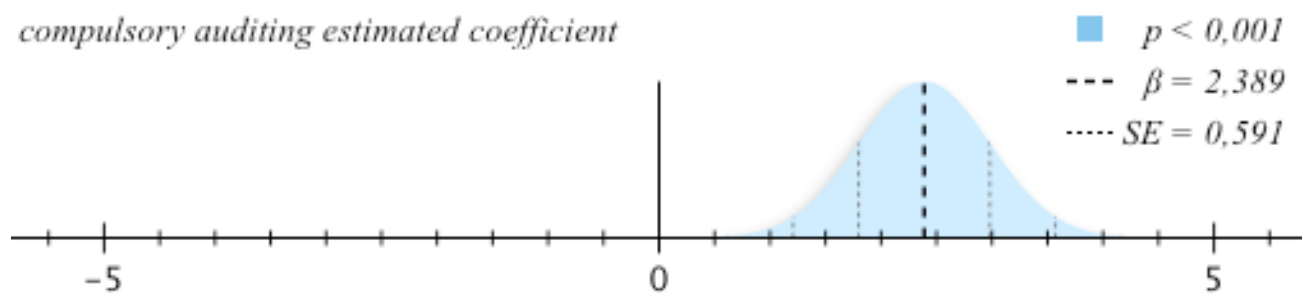

compulsory auditing estimated odds ratio
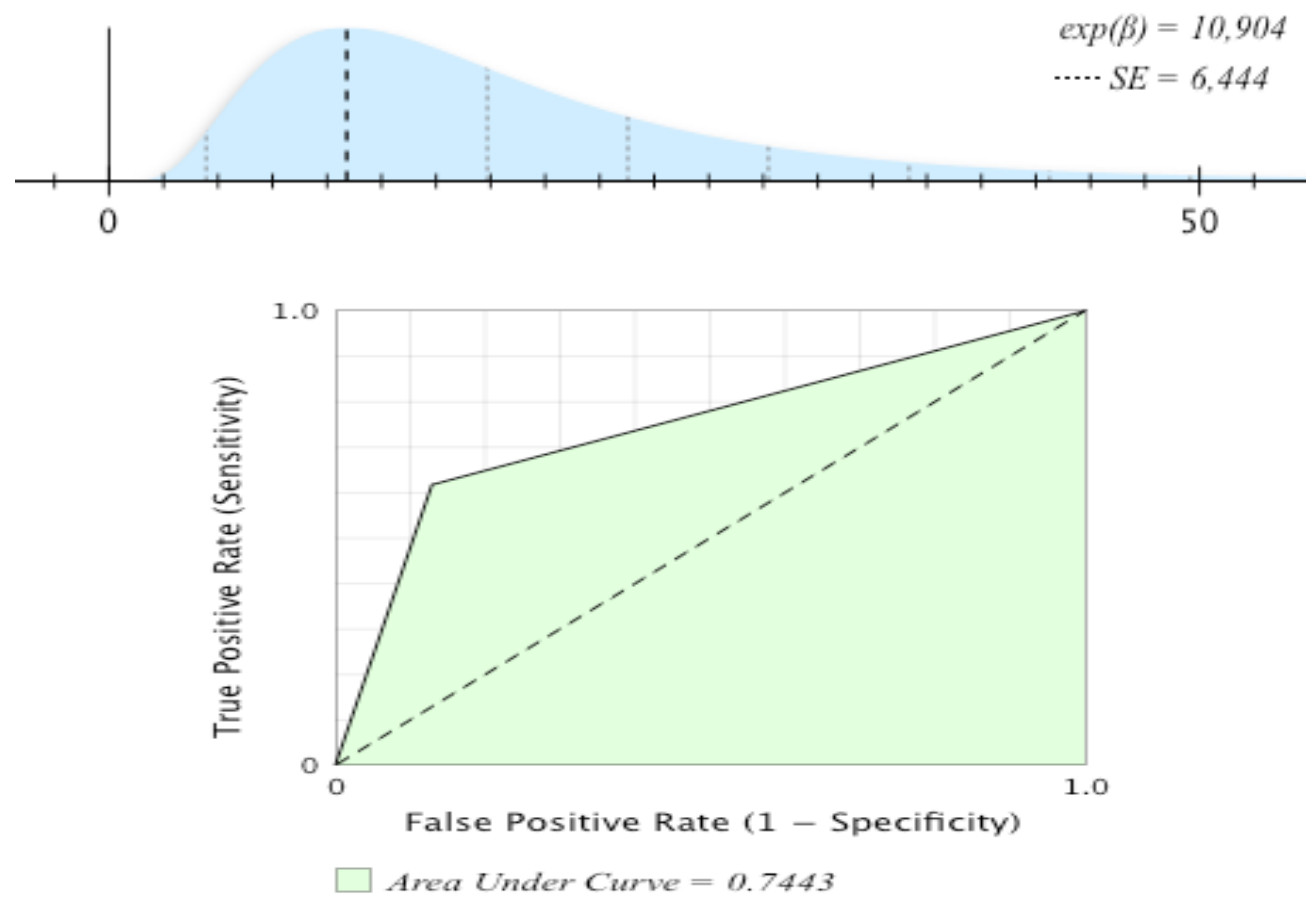

FIGURE 4. THE UNIVARIATE LOGIT ANALYSIS RESULTS: QUALITY OF NOTES BY COMPULSORY AUDITING CRITERION

Source: Authors' calculation 


\section{CONCLUSIONS}

Small and medium-sized enterprises are considered as the "growth engine" of the national economy development. In many countries, the majority of registered enterprises belong to this group. Their importance stems from the fact that they employ a considerable part of work force and contribute significantly to GDP and national export. Because of their unquestionable importance for the economy, it is crucial that SMEs financial reporting framework supports their development by providing relevant information for proper and successful decision making, without extra-burden, with the benefits prevailing the costs.

SMEs financial reporting is not yet harmonized world-wide, the countries provide different models of its regulation - some of them use IFRS for SMEs, while some countries use national set of standards or local GAAP, or even tax regulation, company laws, etc. Croatia has regulated SMEs financial reporting by Accounting Act that requires the implementation of national set of standards - CFRS.

In the focus of this paper are the notes to financial statements, and their quality, which is indicated by the level of compliance with CFRS. In order to assess the quality of notes, we limited our research to the notes on revenues and expenditures disclosures, supposing that majority of SMEs would encounter transactions generating revenues and expenditures. So, the quality of notes was estimated by grading the level of compliance with CFRS 15 (Revenues) and CFRS 16 (Expenditures) disclosures requirements in notes. Then, we were looking for the variables of possible influence onto quality of notes.

Considering the research results, size and obligation to perform compulsory audit are both significantly correlated to the quality of notes implicating that medium enterprises and subjects to compulsory auditing have better implemented CFRS, in this case, regarding revenues and expenditures disclosures. The latter also presents the limit of this research and broader research regarding other fields of disclosures are expected, as well as broader research of other aspects of CFRS compliance, particularly from the financial reports users point of view. While for CFRS Board, compliance of medium enterprises financial reports with CFRS (regarding revenues and expenditures disclosures) could be considered as a success, that also necessarily doesn't' $t$ reflect meeting the users needs in the same time. That would require another research and matching the results should bring us to final estimates of CFRS real success in the SMEs everyday business. Even the research performed under these limits has brought us to conclusions upon poor compliance by small entities in the field of notes segment regarding revenues and expenditures disclosures. That raises the question about the level of their acceptance in general by small enterprises, leading to the need for improvement of current CFRS considering further simplifying of their requirements for small enterprises. There's a need for a new standard (e.g. CFRS 18) intended for the smallest - micro enterprises. Such steps are proposed in line with recent EU Directives improvements and IASB guidance on IFRS for SMEs developed for micro-sized entities. This research supports the latter intentions worldwide, encouraging also national regulators to move forward towards the smallest entities reporting needs, hopefully bringing to refinements and simplifications that would care about the organization capacity and the users needs, to improve de facto CFRS, as well as IFRS for SMEs implementation by small, and of course, by their subgroup of micro-sized enterprises.

We believe the results developed from the national perspective could be easily stretched to the international perspective - just like it has been internationally debated regarding differen- 
tial reporting for SMEs versus large enterprises, the debates grow more deeply towards small, particularly micro-sized entities in the SMEs group. The difference in the standards acceptance and disclosure quality between medium versus small (micro) entities probably arises both from unequal organization capacity and the type of users needs. We believe such a difference in disclosure quality is even stronger when it comes to medium versus small (micro) than large versus medium entities. Furthermore, considering the regulation "tradition" of the former transition countries like Croatia, an exhausting extent of detailed rules changing very often, there's plenty of time and resources spent on different sets of business rules following, leaving little space for disclosure quality improvements, particularly for the overburdened smallest entities. Considering their high share in the total number of entities in any country, they deserve more attention to build their simple and effective reporting framework. 


\section{REFERENCES}

Albu, Cătălin Nicolae et. al., "An Analysis of the Suitability of the IFRS for SMEs Implementation in Romania, the Czech Republic, Turkey and Hungary", International Conference, Accounting Renaissance, Lessons from the Crisis and Looking into the Future, Learning from Histories and Institutions, Universita Ca' Foscari, IAAER, Financial Reporting Journal, (Venice, 3-5 November 2011), 1-23

Baldarelli, Maria Gabriella, Demartini, Paola and Mošnja-Škare, Lorena. "Primjena računovodtsvenih standarda u malim i srednjim društvima Italije i Hrvatske: Izazovi međunarodne harmonizacije," Ekonomska istraživanja 20, no. 1 (2007): 8-25.

Baldarelli, Maria Gabriella, et al. "Accounting harmonization for SMEs in Europe: Some remarks on IFRS for SMEs and empirical evidence", Ekonomska istraživanja 25, SE 1 (2012): 1-26

Maria-Gabriella Baldarelli, Paola Demartini and Lorena Mošnja-Škare, "International accounting for SMEs: Empirical evidence from SMEs in a country in transition and a developed country facing new challenges, (Pula: Juraj Dobrila University of Pula, 2007.)

Ball, Ray, Kothari S. P. and Robin, Ashok. "The Effect of International Institutional Factors of Properties of Accounting Earnings," Journal of Accounting and Economics 29 (2000): 1-51.

Ball, Ray and Shivakumar, Lakshmanan. "Earnings Quality in UK Private Firms.," Journal of Accounting and Economics 39 (2005): 83-128.

“BIZNET - inteligentni sustav poslovnih informacija”, accessed April 05, 2013. http://www1.biznet. $\mathrm{hr} / \mathrm{hgkweb} / \mathrm{do} / \mathrm{advsearch}$.

Carsberg, Bryan et. al.. "Small Company Financial Reporting", Prentice Hall International- ICAEW, London (1985).

Croatian Accounting Act, The official gazette - NN 109/07, 54/13

Croatian Audit Act, The official gazette - NN 146/05, 139/08, 144/12

Croatian act on supporting of small entrepreneurship development, The official gazette - NN, 29/02, 63/07, 53/12, 56/13.

Croatian financial reporting standards, The official gazette - NN 30/08, 4/09, 58/11, 140/1, accessed August 10, 2013. http://www.porezna-uprava.hr/hr_propisi/_layouts/in2.vuk. sp.propisi.intranet/propisi.aspx\#id=pro1230

“CEPOR: Izvješće o malim i srednjim poduzećima u Hrvatskoj - 2011.”, accessed August 10, 2013. http://www.cepor.hr/SME\%20godisnjak_final.pdf

Cole, Vicky, Branson, Joël and Breesch, Diane. "Are users of financial statements of publicly and non-publicly traded companies different or not? An empirical study." accessed at January, 19, 2014. (http://papers.ssrn.com/sol3/papers.cfm?abstract_id=1407566)

Dečman, Nikolina. "Financijski izvještaji kao podloga za ocjenu sigurnosti i usješnosti poslovanja malih I srednjih poduzeća u Republici Hrvatskoj", Ekonomski pregled 63, no. 7-8 (2012): 446-467

Deaconu, Adela et. al., "Analysis of the stakeholders 'needs and their inference financial report of SMEs", Journal of international business and economics, Vol. 9, No. 1 (2009), 39-52 
Paola Demartini and Eugenia Palazzi, "Basel 2 effects on SME financial reporting" in "Accounting for SMEs: Multidimensional aspects and global challenges" ed. Lorena Mošnja- Škare (Pula: Juraj Dobrila University of Pula, 2007.), 37-56

Di Pietra, Roberto. "IFRS for SMEs and EU Accounting Directives Modernization" (paper presented at EAA 33rd Annual Congress, Istanbul, May 2010.)

Directive 2012/6/EU of the European parliament and of the council of 14 March 2012 amending Council Directive 78/660/EEC on the annual accounts of certain types of companies as regards micro-entities, Official Journal of the European Union, L 81/3, 2012, accessed August 14, 2013. http://eur-lex.europa.eu/LexUriServ/LexUriServ.do?uri=OJ:L:2012:081:00 03:0006:EN:PDF

Evans, Lisa et al.. "Problems and opportunities of an International Financial Reporting Standards for Small and Medium-sized Entities. The EAA FRSC's Comment on the IASB's Discussion Paper, Accounting in Europe, vol. 2 (2005): 25-45

“Exchange rates”, Croatian National Bank, accessed August 8, 2013. http://www.hnb.hr/tecajn/

FINA Register of financial reports, accessed April 05, 2013, http://rgfi.fina.hr/JavnaObjava-web

“Guidance for Micro-Sized Entities", IASB, accessed August 24, 2013. http://www.ifrs.org/IFRSfor-SMEs/Pages/Guidancemicrosizedentities.aspx

Hagigi, Moshe. "Accounting Disclosure: Small Versus Large Companies", in L'armonizzazione dei principi contabili in Europa. "Quali regole" per le piccole e medie imprese?, ed. Gianfranco Capodaglio and Maria G. Baldarelli (ROMA, Rirea, 2006) 241-259.

IFRS application around the world, Jurisdiction Profiles, accessed January, 15, 2014., http://www. ifrs.org/Use-around-the-world/Pages/Jurisdiction-profiles.aspx

“IFRS for SMEs”, IASB, accessed August 11, 2013. http://eifrs.iasb.org/eifrs/sme/en/IFRSforSMEs2009.pdf

Logistic Regression, accessed August 24, 2013, http://www.saedsayad.com/logistic_regression. htm

Morris, Paula and Campbell, Jane. "Big GAAP-Little GAAP - Does One-Size-Fits-All Still Work?", Journal of Business \& Economics Research 4, No. 5, (2006): 73-82.

Pacter, Paul and Scott, Darrel. "The IFRS for SMEs" (paper presented at IFRS Conference, Dubai, September 14, 2012), accessed August 14, 2013, http://www.ifrs.org/IFRS-for-SMEs/ Documents/1209SMEsDubai.pdf

Paoloni, Mauro and Demartini, Paola. "Small company financial reporting: users and information needs" (paper presented at the 20th Annual Congress of the EAA, Graz, Austria, 1997).

Pascu, Ana-Maria and Vasiliu, Andreea. "International financial reporting standard for small and medium-sized entities - a new challenge fro the European Union", Centre for European Studies (CES) Working Papers;2011, Vol. 3 Issue 1 (2011): 121-134

Quagli, Alberto and Paoloni, Paola. "How is the IFRS for SMEs accepted in the European context? An analysis of the homogeneity among European countries, users and preparers in the European commission questionnaire", Advances in accounting, Vol. 28, No. 1 (2012), 147-156 
Ramljak, Branka. "Stanje i perspektive razvoja financijskog izvještavanja za mala i srednja poduzeća", in: Računovodstveno izvještavanje u RH i harmonizacija sa zahtjevima EU, ed. Ramljak, Branka (Split: Ekonomski fakultet, 2009), 21-46.

Ramljak, Branka and Žager, Katarina. "Stanje i razvoj financijskog izvještavanja malih i srednjih poduzeća u RH i EU", Računovodstvo i financije 59, no. 7 (2013), 23-31

"Simplifying financial reporting for micro entities", Accountancy SA, accessed August 25, 2013, http://www.accountancysa.org.za/resources/ShowltemArticle. asp? Articleld $=2536 \&$ Issue $=1121$

Smrekar, Nikolina. "Usklađivanje nacionalne i međunarodne regulative financijskog izvještavanja malih i srednjih poduzeća", Zbornik Ekonomskog fakulteta u Zagrebu 7. no. 2 (2009), 89-100

UNCTAD, "Accounting and financial reporting guidelines for small and medium-sized enterprises (SMEGA), Level 2 guidance", (New York and Geneva: United Nations, 2004), accessed at August 13, 2013, http://unctad.org/en/Docs/iteteb20035_en.pdf

Vansteeger, Veerle. "The current state of accounting harmonization: impediments to and benefits from harmonization," working paper D/2005/7012/40, Department of Accountancy and Corporate Finance, Ghent University August 2005, 2005/322.

Žager, Katarina. "Osnovna obilježja i značaj MSP u gospodarskom razvoju”, in Harmonizacija i standardizacija financijskog izvještavanja malih i srednjih poduzeća, ed. Žager, Katarina (RIF, Zagreb: HZRIF, 2013), 11-30. 